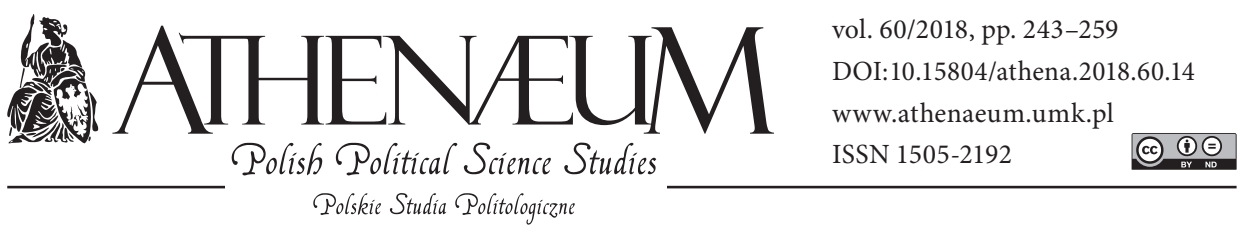

\title{
A CONTRIBUTION TO THE RESEARCH \\ ON ANTI-TRANSFORMATIONAL LEADERSHIP \\ AS A FORM OF GOVERNANCE IN NON-DEMOCRATIC REGIMES
}

\author{
PRZYCZYNEK DO BADAŃ WODZOSTWA \\ ANTYTRANSFORMACYJNEGO JAKO SPOSOBU \\ SPRAWOWANIA WŁADZY W REŻIMACH \\ NIEDEMOKRATYCZNYCH
}

Judyta Bielanowska*๑

\begin{abstract}
The aim of this article is to illustrate the specificity of the functioning of power mechanisms in non-democratic systems, with particular emphasis on the relations between entities of a cratic structure, i.e., the person exercising the highest power in the hierarchy of a socio-political system vs the ruling elite, the ruling elite vs the ruling class, and the ruling class vs social masses. Moreover, based on current research in the area of governance in authoritarian and totalitarian systems, conceptualisation was performed on anti-transformational leadership, which is a theoretical category reflecting in the fullest possible way the essence of relations of domination and subordination between the ruling and the ruled in regimes with a permanent deficit of legitimation, whose constitutive feature consists in the desire to
\end{abstract}

Celem niniejszego artykułu jest ukazanie specyfiki funkcjonowania mechanizmów władzy w systemach niedemokratycznych, ze szczególnym uwzględnieniem relacji między podmiotami struktury kratycznej, tj. osobą sprawującą najwyższą władzę w hierarchii systemu społeczno-politycznego a elitą rządzącą, elitą rządzącą a klasą rządzącą oraz klasą rządzącą a masami społecznymi. Ponadto w oparciu o dotychczasowe badania z zakresu sprawowania władzy w systemach autorytarnych i totalitarnych, konceptualizacji poddano wodzostwo antytransformacyjne, stanowiące kategorię teoretyczną oddającą w sposób możliwie najpełniejszy istotę stosunków dominacji i podporządkowania między rządzącymi a rządzonymi w reżimach o trwałym deficycie legitymacji, których cechą konstytutywną jest

* Nicolaus Copernicus University in Toruń, Faculty of Political Sciences and International Studies. 
ensure absolute obedience of particular subjects of the socio-political hierarchy. Furthermore, an exemplification of the indicated relationship was provided by reference to the erosion of totalitarian leadership in the political system of the Polish People's Republic.

Keywords: anti-transformational leadership, ruling elite, ruling class, social masses, Polish People’s Republic dążność do utrzymania w pełnym posłuszeństwie poszczególnych podmiotów hierarchii społeczno-politycznej. Dokonano również egzemplifikacji wskazanej zależności przez odwołanie do erozji wodzostwa w systemie politycznym Polskiej Rzeczpospolitej Ludowej.

Słowa kluczowe: wodzostwo antytransformacyjne, elita rządząca, klasa rządząca, masy społeczne, Polska Rzeczpospolita Ludowa

The specificity of functioning of the socio-political system in non-democratic regimes opens a wide field for research on the state of empowerment of particular components of a holistically understood system of dependence and subordination between individual entities of a cratic structure (i.e., the structure of power), and, hence, the relationship between dominant political forces and subordinated groups on the principle of imposed and incessantly enforced obedience. This article shall therefore use the example of governance in the Polish People's Republic (PRL) to demonstrate the mechanisms of subordination of particular entities of the power structure to superior authorities, as well as it will carry out operationalisation on the basic theoretical category reflecting, to the widest possible extent, the essence of governance in all non-democratic regimes, with particular inclination towards the totalitarian regime. Indeed, in the current research on the theory of governance in non-democratic regimes, particularly among English-speaking authors, the dominant term is 'totalitarian leadership', which seems to be largely inadequate with regard to defining the specificity of governance in systems with extremely undemocratic qualities ${ }^{1}$. Therefore, based on the hypothetical-deductive method, it seems justified to reflect on the possibility of using the category of 'totalitarian leadership' in relation to nondemocratic regimes.

1 Polish literature is dominated by the belief that political leadership cannot by nature be totalitarian, because as a relation of voluntary submission of supporters of a political leader it necessarily excludes any coercion in this respect (see, inter alia, a markedly analytical study by P. Żukiewicz (2011)). Whereas the classic book in the field of research on political leadership which excludes the existence of a political leadership in totalitarian regimes, is that by: J.M. Burns (1979), where the author clearly contraposes political leadership against absolute power on the principle of antinomy. 


\section{POLITICAL VS ANTI-TRANSFORMATIONAL LEADERSHIP}

The literature on the subject matter referring to 'totalitarian leadership' mainly includes studies dating back to the 1930s. It is worth pointing out such authors dealing with the issues of governance in non-democratic regimes as Aleksander Hertz or James MacGregor Burns. The former, in his essays titled The Mission of the Ruler (1994) and The Team of the Ruler (1994), refers to totalitarian leadership as a kind of relationship between an individual endowed with charisma, generally identified by the author with the 'mission', and subordinate masses, as well as points to a number of multilateral connections between the ruler and his most trusted and closest environment referred to as the 'ruler's team'. However, despite the fact that the aforementioned essays could be an inspirational reading for those seeking to formulate the definition of 'totalitarian leadership' in relation to the First Secretaries of the Central Committee of the Polish United Workers Party (PZPR), it is because of the fact that the author identifies the 'ruler' with the 'leader' that it is impossible to make a distinction between these concepts on the basis of the said studies, while such a theoretical manoeuvre would be appropriate from the point of view of the adopted category. Furthermore, the said studies lack the attempt to conceptualise the notion of 'totalitarian leadership' as a relationship of power. The works of Aleksander Hertz are rather case studies referring to Hitler, as well as, to a lesser extent, to Stalin, who, in the conviction of the Polish sociologist, are leaders par excellence.

In turn, James MacGregor Burns in Leadership (1979) demonstrates the diversity of leadership relations by reference to the continuum defined by antinomian ideal types, namely leadership and absolute power. He looks at the notion of leadership from two angles. On the one hand, he sees it as a simple exchange between the leader and the supporters, who in return for representing their interests by the political leader offer him their support, yet there is no deeper bond between the two entities involved in the process or a relation of leadership. Thus, in this case we are dealing with transactional leadership, which finds no reference to the multi-entity structure of dependencies in the system of governance in the PRL, primarily due to its hierarchisation and lack of a direct relationship between the first secretary of the Central Committee of the PZPR and the social masses. However, the second type of leadership specified by Burns, namely transformational leadership, seems worth considering in the context of 'totalitarian leadership'. This kind of leadership consists in permanent striving of the leader to raise to a higher level the empowerment of 
both himself and those voluntarily subordinated to him. Thus, by transposing the definition of transformational leadership onto the ground of deliberations on totalitarian leadership, one may analyse them by juxtaposing transformational leadership with its anti-transformational counterpart. In this context, the latter would constitute a sub-type of totalitarian leadership, likely to exist in a non-democratic political reality. Therefore, in this respect, the use of the typology proposed by Burns seems to be justified, provided it can be subject to a certain modification.

\section{ANTI-TRANSFORMATIONAL LEADERSHIP IN NON-DEMOCRATIC REGIMES}

Annebel De Hoogh, Lindred Leura Greer, \& Deanne Den Hartog in the article Diabolical Dictators or Capable Commanders? An Investigation of the Differential Effects of Autocratic Leadership on Team Performance (2015, pp. 687-701) analyse the possible behaviours of groups subordinated to an authoritarian individual. And although the content of the article deals with the relationship of dependence and subordination in an organisation that is by no means political, the general assumptions can be transferred onto the ground of considerations about power as a social relation, and particularly about totalitarian leadership. Thus, the above-mentioned authors argue that although authoritarian leadership commonly evokes clearly negative connotations due to the apparently negative impact on the team's performance and cohesion (in the context of these considerations, in line with the nomenclature adopted in the article, a team/ teams should be understood as particular groups subordinated to the leader, i.e., the elite, class and social masses, while the term leadership/authoritarian leader is synonymous with totalitarian leadership/leader), in reality the relations between entities remaining in a hierarchical relationship are slightly more complicated. Namely, the more an autocrat is able to guarantee the subordinated teams security, predictability of the development of situation and conditions for an effective implementation of their goals, his position as a leader remains unthreatened, and the thus far maintained hierarchy is fully approved by his supporters. In turn, in an opposite case when we are dealing with the state of uncertainty of the existing relationship resulting from a sense of threat to the existing state of affairs, and the leader is unable to restore the lost order, the subordination between particular groups is disturbed. What is more, they 
begin to compete for influence, power and, ultimately, for the removal of the current leader whose aspirations are increasingly distanced from common goals pursued by the entire team (De Hoogh, Greer, \& Den Hartog, 2015).

Thus, transposing the above conclusions onto the level of the adopted research assumptions, and, above all, onto the basic theoretical category, it should be pointed out that the loss of a sense of security, the fight between coteries, the lack of convergence of goals, and the disintegration of hierarchical subordination should be linked to the exhaustion of consensus between the leader and subordinate groups. In other words, the way of interpreting authoritarian leadership in the cited article, presented on the background of a hierarchised structure, on the basis of specified conditions for its duration, allows for drawing very general conclusions about the erosion of leadership. However, this requires a far-reaching criticism, resulting from the fact that the article essentially refers to the behaviour in an organisation, or a workplace, and not the area of political power.

The issue of authoritarian leadership in the context of functioning of the party that forms the foundation for the existence of a democratic regime is also addressed by Joseph Wright and Abel Escribà-Folch in the article Authoritarian Institutions and Regime Survival: Transitions to Democracy and Subsequent Autocracy (2012, pp. 283-309). The authors argue that political parties, whose core is their internal non-democratic structure, and which are therefore based on the hierarchisation and centralisation of power, ensure the duration of autocracy, provided that their functioning is rooted in authoritarian legislation, and, thus, probably such that fully protects the authoritarian rule, leaving no legal possibility for democratisation. Otherwise, without a foundation in this kind of legislation, an authoritarian party organisation, even if capable of effectively suppressing internal threats, destabilises the dictatorial rule by laying the ground for democracy, however such democracy is deemed to decompose and return to the initial state, i.e., authoritarian dictatorship. Whereas the possibility of transforming authoritarianism into another non-democratic regime, as assumed by the authors of the referenced article, is negligible. This assumption recalls the theory of circulation of elites of Vilfredo Pareto and Gaetano Mosca, however, apart from references to the classics of sociology opting for seeing the normative system as a weapon of authoritarianism, as well as an indication of the alternating occurrence of authoritarianism and democracy, it is impossible to find in this line of reasoning the causes for the collapse of authoritarian regimes or even a sequence of changes in the position occupied by the dictator/leader. Thus, the theses adopted by Wright and Escribà-Folch do not allow to draw conclusions enabling the conceptualisa- 
tion of erosion of totalitarian leadership, which as a complex process cannot be simply identified with the erosion of a political system, although even in this respect the usefulness of the article would be dubious.

A much greater cognitive value for the adopted theoretical category is found in the book entitled Dictators and Dictatorships: Understanding Authoritarian Regimes and Their Leaders by Natasha M. Ezrow and Erica Frantz (2011). And even though this publication is primarily a review, as it shows various aspects of the functioning of political dictatorships on the background of selected states of the Eastern Europe, Asia and Latin America, it also takes up the problem of longevity of authoritarian regimes and the remaining of their leaders in power. The basic observation of the authors of the book boils down to the fact that the most important characteristic of dictatorships in various regions of the world is the dependence of their survival on the relations between the leader and the elite. The dynamics of this relationship is of course diversified depending on the internal structure of a particular dictatorship, however, the common feature for each of them is the personal dimension of these two entities. An uninterrupted interaction between the leader and his team is therefore the sine qua non condition for the duration of the regime and stabilisation of the leader's position in the ruling structure. In this context, the cited publication has an extremely useful content allowing to note the importance of unconditional subordination of the elite to the leader, because in a situation when these conditions begin to be dictated by the elite, and the status quo is subject to contestation, the previous hierarchy based on multi-party subordination is subject to distortion, and consequently leads to the erosion of power. However, a certain weakness of the analysed book rests in the lack of reference to other dimensions of erosion occurring at the level of the ruling class and social masses. Nevertheless, the indication of destructive implications for the regime's durability in the context of a possible disturbance of the relationship between the leader and its immediate environment (elite) allows for partial interpretation of what in essence the erosion of leadership is in relation to the First Secretaries of the PZPR Central Committee, though certainly it does not exhaust this issue in its entirety.

The problem of survival of an authoritarian regime on the background of the relationship between the leader and subordinate entities is also addressed by Milan W. Svolik in the article Power Sharing and Leadership Dynamics in Authoritarian Regimes (2009, pp. 477-494). Unlike N. Ezrow and E. Frantz, however, the author does not limit himself to analysing the relations between the dictator and the ruling elite, pointing to a slightly different plane of reflections 
on leadership in authoritarian regimes, namely the power of both the leader and the ruling coalition, with the latter term - for the purposes of the present paper, and given the fact that in relation to non-democratic regimes it seems more appropriate to use the term 'ruling elite' rather than the ruling coalition - being equated with the ruling elite. And so, Svolik argues that the division of power, and thus the political influences between the leader and the elite is necessary, because the concentration of these resources solely in the hands of the leader would mean a serious threat of use of violence due to the growing conflict of interests. And although the dictator has the possibility to multiply his impact, use his superior position in the power structure, thus limiting the ruling coalition, in the long-term this kind of political opportunism is certainly not conducive to maintaining the position of a leader and, thus, ensuring the survival of the regime (Svolik, 2009).

The conclusions contained in the article undoubtedly indicate the importance of convergence of the leader's and elite's interests, the necessity of division of power, especially at the level of these two entities, yet in these deliberations we do not find references to the erosion of totalitarian leadership occurring in a much more complicated structure than merely that related to the conflict and fight for power between the ruler and his immediate surroundings. Therefore, the quoted article does not attempt to holistically apprehend the disintegration of an authoritarian regime, let alone see the reasons for its fall in internal factors that do not boil down solely to the leader and his support but also encompass the remaining correlated segments of the hierarchised structure.

However, in the next study, The Politics of Authoritarian Rule (2012), the same author already seems to complement the previously expressed observations regarding the conditions for the existence of an authoritarian regime, indicating that it is necessary for the dictator to solve two problems in order to solidify his position. Firstly, to ensure authoritarian control over the masses subordinate to him, and secondly, the division of power between him and the elite (which was already mentioned in the context of the previously analysed article). More importantly, the solution to these issues favourable for the survival of a regime Svolik sees in the use of violence, which as the 'final arbitrator in a conflict' is perceived as the only effective method of guaranteeing the existence of a given system in a situation where there is no other authorised body to enforce obedience of subordinated entities (Svolik, 2012).

And although the undoubted cognitive value of the discussed argument rests in the recognition of the importance of dictator's control over the masses sub- 
ordinate to him, as well as the possible consequences of ignoring the aspirations of the ruling elite, still the recourse to violence as the final instance in the event of conflict in the above-mentioned areas of governance arouses serious reservations, especially if we assume that the use of terror/violence is not a distinctive feature of the totalitarian system.

It is worth noting, however, that Milan Svolik is not the only author who in his research on totalitarianism assigns an undue role to terror as not only the guarantor of survival of an undemocratic regime, but also perceives it as a distinctive feature of totalitarianism. In fact, Sigrid Meuschel also perceives both terror and ideology in terms of particular elements that characterise this system (2000, pp. 87-98).

From a slightly different perspective, the problem of the dictator's staying in power is shown by Alexandre Debs in Living by the Sword and Dying by the Sword? Leadership Transitions in and out of Dictatorships (2016, pp. 73-84). He tackles the issue of the effect of the dictator's overthrow on his inclination towards the democratisation of the system. And although the author refers in his considerations firstly to military dictatorships and performs analyses of the relationship between the cadence of a given leader and the scope of his use of violence during its duration, it can also be applied to the problem of the loss of leadership in other non-democratic regimes. The most important thesis, whose rightness is proved by Debs, indicates the conviction that the easier it is to eliminate the leader the more is he inclined to use violence, and such violence, with reference to the political system of the PRL, can be identified with the terror used or possible to be used against the society. At the same time, as Debs points out, the dictator, deprived of his superior position in the cratic structure, wishing to retain even a substitute of his previous influence, opts for the democratisation of the system. Thus, the greater the risk of being removed from power, the more likely it is that the option of use of violence will be abandoned (Debs, 2016).

Therefore, in this case the erosion of dictatorship correlates with the use of violence or the threat of its use. The thus formulated relationship would be highly paradoxical, and even doubtful, if it were really assumed that terror constitutes one of the criteria of a totalitarian or authoritarian system. However, if we assume that the use of terror is not the pillar of a non-democratic system, and, what is more, it is not even of secondary importance and remains on the margins of the enumerated factors classifying a given system as totalitarian, then it becomes hard to deny that Debs was right when he assumed that the dictator's position is seriously threatened when he is forced to reach for a reservoir of resources 
based on coercion and police-military terror. Although in this publication there is no reference to the significance of such factors in the erosion of totalitarian leadership as the possibility of gaining political empowerment by the masses, or the conflict of interests between the elite and the ruling class, still the value of the analysed text for these considerations becomes noticeable precisely because of the already signalled connection between the use of terror and the collapse of a given system, that is, inter alia, what has been defined as the 'erosion of leadership'. It is also worth pointing out that the text makes a certain reference to the influence of the faction that can be identified with the ruling elite on maintaining the superior position by the dictator, however this is not particularly highlighted. Much more attention Debs pays to the relationship between the use of violence and the possibility of replacing the dictator.

Whereas with reference to ideology, to which, aside from terror, points the already cited S. Meuschel as the main determinant of totalitarianism, it should be indicated that given the thus far developed concepts of the ideology, the term totalitarian political gnosis seems to be more suitable, as it is distinctive for groups and structures of a totalitarian nature.

In the context of collapse of various types of modern dictatorships, the dependencies which also seem worthy of noting are concerned with the necessity to divide the power between the leader and the ruling coalition ${ }^{2}$ as the basic condition for survival of an authoritarian regime from the point of view of Beatriz Magaloni expressed in the article Credible Power-Sharing and Longevity of Authoritarian Rule (2008, pp.715-741). Magaloni proves that the guarantor for the lasting of an authoritarian system is the division of power which, although established by the dictator, must be sufficiently convincing for his 'loyal friends' so that the risk of overthrowing the system by the ruling elite, and thus depriving the current dictator of the ruling resources, becomes reduced to a minimum. Hence, according to the author of the article, the durability of a non-democratic regime is secured by the elite's constant readiness to invest in the existing authoritarian institutions, whose chances of survival thereby become greater regardless of the level of threat posed by counter-elite and the 'rival' claiming the ruling position on its behalf (Magaloni, 2008).

2 Similarly to the already cited article by M. Svolik Power Sharing and Leadership Dynamics in Authoritarian Regimes, also in this one, for the sake of a greater clarity of the argument, the ruling coalition should be identified with the ruling elite. 
Thus, both Svolik and Magaloni point to the importance of the relations between the dictator and his closest environment, seeing in them the spiritus movens for the survival or collapse of a non-democratic system. Unlike Svolik, however, Magaloni does not see the importance of participation of other entities in the power structure, which, at least potentially, could influence the ruling decisions, namely those of the ruling class and social masses. In this respect, the aforementioned author does not engage in reflection. Although it is difficult to deny that the ruling elite has a far-reaching impact on the dictator's position, the disregard of the possibility to generate change in the political power system by other factors does not allow for reaching reliable conclusions about the erosion of leadership in a non-democratic system.

However, in addition to the importance of the relationship between the leader and the elite and the problem of division of power between these entities as a condition necessary for the survival of a given system, it is worth noting the significance of charisma, which as a factor inscribed in the essence of totalitarian leadership, or any other relationship of power characteristic for non-democratic systems, requires a broader discussion.

Jaepil Choi in the article A Motivational Theory of Charismatic Leadership: Envisioning, Empathy and Empowerment (2006, pp. 24-43) indicates that a charismatic leader not only has the ability to anticipate, empathise and initiate desirable behaviours of his followers, but also has the ability to create the sense of belonging in people subordinated to him, who have thereby a clearer idea of their role and are capable of creating the collective identity of their group. In other words, a charismatic leader becomes the guarantor of lasting and, what is more, voluntary obedience of his 'followers' who derive satisfaction from the mere fact of belonging among the supporters of the leader. Hence, according to the author, the essence of charisma consists in the motivational abilities of a leader. And although J. Choi's context for the analysis of charisma with regard to the relationship between the leader and the supporters is a workplace, on the basis of these considerations we can make reference to some of the aspects that fit into the political sphere. In particular, this applies to collective identity, which may constitute an expression of convergence of interests at the level of the ruling class. On the other hand, the possibility of influencing subordinate entities and initiating their behaviour does not have to or should not be limited solely to the closest and directly subordinated group of people. Indeed, concerning social relations, particularly the relation of power, charisma has a much wider scope and encompasses also social masses, not just the elite, or, possibly, the 
ruling class. However, it is hard to expect such a far-reaching conclusion from the author, especially since in the central point of his article he places the effect of the leader's charisma on increasing productivity in the workplace from the perspective of the group's cooperation. Nevertheless, an undoubted advantage for the operationalisation of charisma is the indication of certain distinctive features that facilitate its differentiation from concepts with similar connotations, such as influence or authority.

However, Mark G. Ehrhart and Katherine J. Klein raise the issue of an effect of charisma on particular, ever wider circles of 'followers' in the article Predicting Followers' Preferences for Charismatic Leadership: The Influence of Followers' Values and Personality (2001, pp. 152-179). In the opinion of the authors, followers are not only the background or the social ground for the charismatic impact of the leader but also play a fundamental and active role in the creation of 'charismatic relations', i.e., such connections in which the leader's charisma can truly manifest itself depending on the followers' system of values and personality. In addition, according to Ehrhart and Klein (2001), their placement or structural distance from the leader, is also significant. In reference to the totalitarian leadership in the PRL, this can be treated as a hierarchical structure of subordination to the First Secretary, which, however, does not limit the possibility of participating of even the social masses in the leader's charisma, the masses which are in fact the most distant entity subordinated to the leader. And probably this is the very essence of the leader's charisma, which does not only affect the immediate environment but increasingly gains ground within the social structure. Since if it were limited only to the 'leader's team' or even to the ruling elite, we would rather be faced with pseudo-charisma which is a consequence of the deinteriorisation process, however it should be pointed out that both the routinisation of charisma and pseudo- (quasi)charisma is at times an extremely long-lasting process. Thus, what we deal with is a one-off and immediate act. Moreover, pseudo-charisma may be a reflection of far-reaching opportunism, calculated to maintain the possessed sphere of influence, as guaranteed by the person currently holding the highest authority.

In turn, the problem of erosion of charisma is addressed by Jennifer L. Merolla and Elizabeth J. Zechmeister in the article The Nature, Determinants and Consequences of Chávez's Charisma: Evidence from a Study of Venezuelan Public Opinion (2011, pp. 28-54). Based on opinion polls regarding the evaluation of the president of Venezuela, the authors prove that it is proportional to Chávez's perception as charismatic, i.e., the more he is seen as a person endowed 
with charisma, the higher is the respondents' assessment. At the same time, they demonstrate that erosion of charisma is a dynamic process, and, consequently, it is accompanied with an equally dynamic drop in support for the leader who was previously regarded as an emanation of charisma as a quality with positive connotations (Merolla \& Zechmeister, 2011). Thus, in this case we observe a correlation between the perception of the leader as charismatic and the permanence of acceptance and support for him. On the basis of considerations concerning the erosion of totalitarian leadership, the charisma of a ruler can be therefore perceived as one of the conditions for stabilisation of his superior position in the structure of power. And although admittedly the authors do not concentrate in their deliberations on the consequences of losing charisma for the whole system, in the context of demonstrating certain clear dependencies when it comes to the possession of charisma or the lack of it, one can draw a general conclusion that the exhaustion of this special feature implies refusal of obedience on the part of followers on various levels of subordination. Thus, charisma, as one of the ruling resources, acquires considerable importance for the understanding and depicting of the complexity of the process of erosion of totalitarian leadership, and sometimes even the collapse of a given regime.

On the other hand, the aforementioned J. Wright and A. Escribà-Folch point to a completely different aspect in the replacement of leaders in the article Dealing with Tyranny: International Sanctions and the Survival of Authoritarian Rulers (2010, pp. 335-359), where they address the issue of the effect of external, international economic sanctions on the ability of authoritarian rulers to maintain their position. They argue that the loss of permanent support from foreign entities greatly contributes to the destabilisation of the political system, thus favouring a much more frequent replacement of leaders as compared to other types of dictatorships, e.g., military ones.

The undoubted advantage of this text rests in the recognition of importance of an external factor determining the erosion not only in the political system, but also the replacement in the ruling position, and, therefore, what can obviously be referred to the erosion of totalitarian leadership in the PRL system, which throughout its duration was dependent, both politically and economically, on the Soviet Union. Thus, the possibility of imposing economic sanctions or, going somewhat beyond the content of Wright and Escribà-Folch's article, any impact of an organ, institution or state with a strong and stable international position, constitute a powerful catalyst for transformation in a holistically understood system of a subordinate state, particularly when it comes to the exchange at 
the most significant political position. Thus, the authors cited show the erosion in the system/totalitarian leadership from a completely different perspective, which is undoubtedly worth considering in the context of the adopted theoretical category. Indeed, we are dealing here not only with an arbitrary recognition of the importance of a two-party relationship (ruler - ruling elite) in the context of the necessity of division of ruling resources, but also with the illustration of a certain novum in the analysed subject matter, especially in contrast to those authors who in their considerations omitted the aspect of external interactions and their impact on the destabilisation of a given regime, which in correlation with internal conditions, and thus the mutual subordination of entities in the structure of power, may prove extremely useful in the process of conceptualisation of the erosion of totalitarian leadership in non-democratic systems typologically similar to the PRL system.

The next paper, which is worth analysing in the context of the adopted theoretical category, is an article by Roman Bäcker The Porcelain Fragility of Authoritarian States (2015, pp. 47-55). The author attempts to answer the question: what causes the states with an authoritarian system that seem to be durable, stable and impressive due to their apparent ability to survive the most powerful crises, to collapse completely unexpectedly under the influence of a 'secondary shock'. According to R. Bäcker (2015), the reasons for this state of affairs should be seen not in external factors in relation to a given political system but in the mechanisms existing within the system. In addition, the author, while demonstrating the validity of his thesis based on theories of scientists addressing the subject of stabilisation and the fall of authoritarian regimes, conducting a certain synthesis, and at the same time submitting some of the conclusions contained in them to criticism, creates a cognitively valuable depiction of the structure of subordination and hierarchy, on the basis of which these mechanisms can operate.

An undoubted advantage of the text is the recognition of significance of the following aspects for the durability of an authoritarian regime: commonality of interests of the ruling class articulated by the ruling party; control over the masses, which are thereby kept in the state of political objectification and are thus incapable of articulating their interests, form the political opposition, and, particularly, select a counter elite that could be an effective counterbalance to the currently ruling elite; the need to divide the ruling resources between groups of significant importance within the ruling class and the importance of charisma, whilst it is worth noting that in line with the author's belief, charisma is exhausted relatively quickly, and therefore it cannot be an effective tool in system legitimisa- 
tion, hence in a long run, it cannot become a factor ensuring cohesiveness within the ruling class or conformism within the social masses. Moreover, a noteworthy observation of the author is an indication that the existence of an authoritarian regime is based on a fragile balance between the masses and the ruling class (Bäcker, 2015).

Thus, the article contains everything that from the point of view of the adopted theoretical category may constitute its essence, i.e., above all the indications that a non-democratic system collapses under the influence of internal factors concentrated within a complex cratic structure and complicated relationships between its subjects. An additional value of the text is that it comprehensively addresses both the importance of charisma and the necessity to take into account the aspirations of members of the elite or the significance of commonality of interests of the ruling class and others, whose importance was either completely overlooked or marginalised in the deliberations of the previously cited authors. Thus, in this case we are dealing with an attempt of a comprehensive demonstration of systemic mechanisms, whose occurrence or intensity may lead to the collapse of an authoritarian system. Nonetheless, it should be assumed that the fall of a given system is an effect of operation of internal systemic mechanisms, which is a kind of a process, hence it cannot be sudden and unexpected. And although an external observer may ascribe to the collapse of an authoritarian regime the 'fragility of a porcelain vase', in fact they should point to a process of system collapse, especially if we assume that the occurring erosion of totalitarian leadership is dynamic, temporal and gradual, rather than being something that cannot be predicted, let alone analysed as a specific causal sequence. When it comes to the political system of the People's Republic of Poland, an example of a leader seeing his decadent political activity as erosion of leadership/power, while being fully aware of this fact, was Wojciech Jaruzelski.

\section{CONCLUSIONS}

Thus, on the basis of all the analysed texts and the there-contained interpretations of the nature of non-democratic systems, and above all the reasons for their collapse, it seems appropriate to apply such a conceptualisation of the 'erosion of leadership' which would primarily constitute an innovative approach to the category of 'leadership' not only with regard to the political system of the Polish People's Republic but also to related systems, i.e., those that formed the 
foundation for the states remaining in the orbit of the Soviet Union's influence and, moreover, which evolved from totalitarianism to democracy. Thereby, the dynamic nature of the political system of a given state, and hence its transpositions encompassing the transitional states, for instance: totalitarianism - limited democracy - consolidated democracy, give grounds for the application of the above mentioned terminology, particularly the one referring to the First Secretaries of the Central Committee of the PZPR as 'leaders'.

Therefore, starting with the term 'erosion', it should be pointed out that although this is not a concept originating from the field of political sciences, its interpretation remains quite unambiguous. Indeed, 'erosion' is a process that is the opposite of what it concerns in a given context. It is not a single act, a sudden event, having no reference to specific conditions - in the discussed case, socio-political ones. On the contrary, its context is always very clearly defined, with distinguishable individual stages. Thus, with reference to 'totalitarian leadership', erosion is a process of gradual annihilation of all those components that constitute a given social relationship as a leadership.

Totalitarian leadership itself, whose immanent feature is being anti-transformational ${ }^{3}$, is a ruling relationship based on a hierarchical, centralised structure ${ }^{4}$, designated by entities to which they belong: First Secretary - ruling elite - ruling class - social masses.

The 'erosion of totalitarian leadership', on the other hand, should be treated as a process opposed to the acquisition of such leadership, and therefore signifying the process of its loss with the final effect being a personal change in the position belonging to the current leader. The essence of the thus understood process is the breakdown of obedience at every level of the cratic structure in relation to the most significant planes of mutual relations between its subjects:

a) First Secretary of the PZPR Central Committee (leader) - ruling elite:

- deinteriorisation of the leader's charisma, or pseudo-charisma, with one of the basic criteria consisting in the growing distance to the social role

${ }^{3}$ Cf. previous considerations on the typology of J. Burns.

${ }^{4}$ Hierarchy and centralisation of the ruling structure is important because, unlike political leadership one of the basic features of which is the symmetry and directness of the relationship between the leader and his voluntary supporters, totalitarian leadership is a mediated relationship, i.e., the commander has a direct contact with broadly understood social masses only in exceptional circumstances, and, in principle, the intermediate levels between him and the general public are the ruling elite and the ruling class. Thus, the hierarchy and centralisation between individual entities become obvious and even necessary. 
of the members of the ruling elite participating in the leader's charisma or pseudo-charisma;

- the formation of a counter elite within the party-state apparatus;

b) ruling elite - ruling class:

- reduction of the importance of political gnosis in the process of political communication;

- the disintegration of identity of interests within the party-state apparatus;

c) ruling class - social masses:

- the possibility of articulation and aggregation of interests of social masses;

- the process of acquiring empowerment by social masses.

\section{REFERENCES:}

Bäcker, R. (2015). The Porcelain Fragility of Authoritarian States. In: R. Wiszniowski (ed.), Challenges to Representative Democracy: A European Perspecitve (pp. 47-55). Frankfurt am Main, Berlin, Bern, Bruxelles, New York, Oxford, Warsaw, Vienna: Peter Lang GmbH.

Burns, J.G. (1979). Leadership. New York: Harper Perennial.

Burns, J.G. (1995). Władza przywódcza. In: J. Szczupaczyński (sel. \& anal.), Władza i społeczeństwo: antologia tekstów z zakresu socjologii polityki (pp. 261-273). Warszawa: Wydawnictwo Naukowe Scholar.

Choi, J. (2006). A Motivational Theory of Charismatic Leadership: Envisioning, Empathy and Empowerment. Journal of Leadership \& Organizational Studies, 13(1), 24-43. DOI: 10.1177/10717919070130010501.

De Hoogh, A.H.B., Greer, L.L., \& Den Hartog, D.N. (2015). Diabolical Dictators or Capable Commanders? An Investigation of the Differential Effects of Autocratic Leadership on Team Performance. The Leadership Quarterly, 26(5), 687-701. DOI: 10.1016/j.leaqua.2015.01.001.

Debs, A. (2016). Living by the Sword and Dying by the Sword? Leadership Transitions in and out of Dictatorships. International Studies Quarterly, 60(1), 73-84. DOI: 10.1093/isq/sqv014.

Ehrhart, M.G., \& Klein, K.J. (2001). Predicting Followers' Preferences for Charismatic Leadership: The Influence of Follower Values and Personality. The Leadership Quarterly, 12(2), 153-179. DOI: 10.1016/S1048-9843(01)00074-1.

Ezrow, N.M., \& Frantz, E. (2011). Dictators and Dictatorships: Understanding Authoritarian Regimes and Their Leaders. USA: A\&C Black.

Hertz, A. (1994). Drużyna wodza. In: A. Hertz, Szkice o totalitaryzmie (pp. 153-266). Warszawa: Wydawnictwo Naukowe PWN. 
Hertz, A. (1994). Posłannictwo wodza. In: A. Hertz, Szkice o totalitaryzmie (pp. 62-152). Warszawa: Wydawnictwo Naukowe PWN.

Magaloni, B. (2008). Credible Power-Sharing and Longevity of Authoritarian Rule. Comparative Political Studies, 41(4-5), 715-741.

Merolla, J.L., \& Zechmeister, E.J. (2011). The Nature, Determinants and Consequences of Chávez's Charisma: Evidence from a Study of Venezuelan Public Opinion. Comparative Political Studies, 44(1), 28-54.

Meuschel, S. (2000). Theories of Totalitarianism and Modern Dictatorship: A Tentative Approach. Thesis Eleven, 61, 87-98.

Svolik, M.W. (2009). Power Sharing and Leadership Dynamics in Authoritarian Regimes. American Journal of Political Science, 53(2), 477-494. DOI: 10.1111/j.15405907.2009.00382.x.

Svolik, M.W. (2012). The Politics of Authoritarian Rule. USA: Cambridge University Press.

Wright, J., \& Escribà-Folch, A. (2012). Authoritarian Institutions and Regime Survival: Transitions to Democracy and Subsequent Autocracy. British Journal and Political Science, 42(2), 283-309. DOI: 10.1017/S0007123411000317.

Wright, J., \& Escribà-Folch, A. (2010). Dealing with Tyranny: International Sanctions and the Survival of Authoritarian Rulers. International Studies Quarterly, 54(2), 335-359. DOI: 10.1111/j.1468-2478.2010.00590.x.

Żukiewicz, P. (2011). Przywództwo polityczne: teoria i praktyka. Warszawa: Difin. 